UDC 519.67

\title{
FAST RATIONAL INTERPOLATION OF TRANSFER FUNCTIONS OF LINEAR DYNAMIC SYSTEMS WITH DISTRIBUTED PARAMETERS
}

\author{
Kodnyanko V. A. - Dr. Sc., Professor, Polytechnic Institute, Siberian Federal University, Krasnoyarsk, Russia.
}

\section{ABSTRACT}

Contex. Fast method of rational interpolation of the transfer function of linear dynamical systems with distributed parameters is described, the values of which can be found by numerical methods or by calculating the transcendental functions of the Laplace integral transform variable. The method makes it possible to determine explicitly the transfer function and, in particular, the characteristic equation of such a degree, which is sufficient to meet the accuracy requirements when calculating the root quality criteria for the dynamics of automatic control systems.

Objective. According to the proposed method, rational interpolation is reduced to solving a system of linear equations, the order of which is much lower (more than twice) the order of similar systems used for rational interpolation of functions by known methods. The properties of this system are such that its solution can be obtained by special fast methods of the quadratic order of complexity.

Method. An iterative algorithm for calculating the transfer function coefficients of a linear dynamic system with distributed parameters is carried out using the methods of complex variable functions theory using the discrete Laplace transform. The proposed approach made it possible to significantly speed up the calculations by decomposing the system of linear equations with respect to the coefficients of the transfer function to a system of approximately half the order, which allows a quick solution by the methods of Trench, Berlekamp-Massey, or Euclid.

Results. An example of the practical use of an iterative algorithm for rational interpolation and calculation with a given accuracy of the root quality criteria for the dynamics of a support with gas lubrication is considered.

Conclusions. The method allows to define explicitly the characteristic equation of such a degree, which is sufficient to meet the accuracy requirements when calculating the root quality criteria for the dynamics of automatic control systems. Rational interpolation is reduced to solving a system of linear equations, the order of which is much lower (more than twice) the order of similar systems used for rational interpolation of functions by known methods. The properties of the system are such that its solution can be obtained by special fast methods of the quadratic order of complexity.

KEYWORDS: rational interpolation, linear dynamic system, transmission function, distributed parameter system, discrete Fourier transform.

\section{ABBREVIATIONS \\ $\mathrm{TF}$ - transfer function; \\ $\mathrm{HP}$ - characteristic polynomial.}

\section{NOMENCLATURE}

\section{$D, F, K, M$ are matrixes;}

$a_{i}, b_{j}$ are transfer function polynomial coefficients;

$f(x)$ is an objective function;

$n, m$ are orders of the polynomials of the numerator and denominator of the transfer function;

$k$ is a sum of the sum of $n$ and $m$;

$p$ is a difference of the orders of the polynomials of the denominator and the numerator of the transfer function;

$s_{i}$ are components of the discrete Fourier transform vector,

$d, l, z$ are vectors,

$\Gamma(\mathrm{s}), \Lambda(\mathrm{s})$ are complex functions,

$\Phi(s)$ is a transfer function,

$\eta, \xi$ are criteria for assessing the quality of the dynamics of linear dynamic systems.

\section{INTRODUCTION}

When designing automatic control and regulation systems, methods for studying the quality of dynamics are used, based on determining its stability margin and speed of response by the roots of the characteristic equation [1, 17]. The latter is determined by the polynomial of the denominator of the transfer function (TF)

$$
\Phi(s)=\frac{\overline{\Delta Y}_{o}}{\overline{\Delta Y}_{i}}=\frac{b_{0}+b_{1} s+b_{2} s^{2}+\ldots+b_{m} s^{m}}{1+a_{1} s+a_{2} s^{2}+\ldots++a_{n} s^{n}},
$$

where $\overline{\Delta Y}_{i}, \overline{\Delta Y}_{O}$ are the Laplace transformants of the deviation of the dynamic functions of the input action and the objective output function from the stationary equilibrium position of the systems, $n>0, m>0, n>m$, $s$ is the variable of the Laplace transform $[2,17]$.

The determination of the coefficients (1) for systems with lumped parameters is usually straightforward. However, there are devices whose dynamics are described by distributed parameter systems. Examples of these systems are a variety of electronic devices, tubular heat exchangers, gas-static and gas-dynamic sliding bearings and a number of others [3-6].

\section{PROBLEM STATEMENT}

For such systems, TF is formulated based on the use of one or more boundary value problems for differential equations, the analytical solution of which is given by transcendental functions, or they can be obtained only by numerical methods [7]. To obtain the TF of these systems, it is necessary to use methods that would provide their representation in the form (1) based on calculating the criteria for the stability margin and speed of devices with a predetermined accuracy.

The representation of the TF in the form (1) falls under the classical problem of rational interpolation [21], the solution of which, however, does not give an 
exhaustive answer to the question of the accuracy of the stability criteria of the system obtained by root methods using the characteristic equation, because the value of the degree $n$ of the characteristic polynomial (HP) is unknown in advance. Consequently, the rational interpolation of the TF is only a local procedure in the general algorithm for determining the quality criteria for the dynamics of systems.

\section{REVIEW OF THE LITERATURE}

Often, when calculating the above criteria, it is required to determine only the vector $a$ of the HP coefficients and its length $n$ in order to be able to determine the root criteria with the required accuracy. In this case, the problem is somewhat simplified, since it is necessary to find only the polynomial of the denominator (1), that is, the HP.

The main task in calculating the quality criteria for the dynamics of systems with distributed parameters at fixed values of $n$ and $m$ is rational interpolation. The existing methods are based on the solution of a linear system of equations for the coefficients (1), which contains $n+m$ equations [4]. Such systems can be solved by general methods, for example, the Gauss-Jordan method, which has a cubic order of complexity $(n+m)^{3}$ (hereinafter, the order of complexity of a computational method means the time complexity of the algorithm that implements it [1, $6]$ ). For large $\mathrm{n}$ and $\mathrm{m}$, this can entail significant expenditures of computer time in the process of multiparameter optimization of dynamic systems.

This article proposes a fast method for finding the coefficients (1). It is based on solving systems of linear equations of a special form of a significantly smaller order, which allows finding their solution by fast methods with a quadratic order of complexity $m(n+m)$, which significantly accelerates the optimization procedure for dynamical systems. If it is required to find only the HP coefficients, then the order of complexity of the method is equal to $n^{2}$.

\section{MATERIALS AND METHODS}

When performing rational interpolation by the method described below, the degrees $n$ and $m$ of polynomials (1) must be known. However, their acceptable values can be obtained only on the basis of a satisfactory accuracy in determining the quality criteria for the dynamics of the system.

If it is impossible to determine the values of these parameters without calculating the mentioned criteria, then finding their difference is not difficult.

Indeed, if $a_{n} \neq 0$ and $b_{m} \neq 0$, then the infinite limit

$$
s^{p} \Phi(s) \rightarrow \frac{b_{m}}{a_{n}} \neq 0,
$$

where $p=n-m$.

Usually the difference $\mathrm{p}$ is calculated in several units, more often $p=1-2$, therefore, this limit and $\mathrm{p}$ can be found rather quickly.

(C) Kodnyanko V. A., 2020

DOI 10.15588/1607-3274-2020-4-5
Let's set the value $m$, define $n=m+p$ and find the coefficient

$$
b_{0}=\Phi(0) .
$$

We rewrite (1) in the form

$$
\begin{aligned}
& a_{1}+a_{2} s+\ldots+a_{n} s^{n-1}+ \\
& +\Gamma(s)\left(b_{1}+b_{2} s+\ldots+b_{m} s^{m-1}\right)=\frac{\Lambda(s)}{s},
\end{aligned}
$$

where $\Gamma(s)=-\Phi^{-1}(s), \Lambda(s)=-b_{0}-\Gamma(s)$.

Equation (3) contains $k=n+m$ unknown coefficients.

Let's calculate $e=\exp \left(-\frac{2 \pi i}{k}\right)$, where $i$ is the imaginary unit.

Let us $s_{1}=1$ and we find $s_{j}=e s_{j-1}, j=2,3, \ldots, k$, $\Psi_{j}=\Phi\left(s_{j}\right), \Gamma_{j}=\Gamma\left(s_{j}\right), \Lambda_{j}=\Lambda\left(s_{j}\right), j=1,2, \ldots, k$.

Note that $s_{j}=s_{k+1-j}^{*}, j=1,2, \ldots, k, \quad$ therefore $\Phi\left(s_{k-j+1}\right)=\Phi^{*}\left(s_{j}\right)$, which allows us to shorten the calculations and find $\Gamma_{j}, \Lambda_{j}$ in $[(k+1) / 2]$ the appeal to the TF.

Substituting $s=s_{j},(j=1,2, \ldots, k)$ in (3), we obtain a system of linear equations for unknown coefficients (1)

$$
M x=y,
$$

where

$$
\begin{gathered}
M=\left[\begin{array}{cccccc}
s_{1} & s_{1} & s_{1} & \ldots & \Gamma_{1} s_{1} & \ldots \\
s_{1} & s_{2} & s_{3} & \ldots & \Gamma_{2} s_{1} & \ldots \\
s_{1} & s_{3} & s_{5} & \ldots & \Gamma_{3} s_{1} & \ldots \\
\ldots & \ldots & \ldots & \ldots & \ldots & \ldots \\
s_{1} & s_{k} & s_{1} & \ldots & \Gamma_{k} s_{1} & \ldots
\end{array}\right], \\
x=\left[\begin{array}{c}
a_{1} \\
a_{2} \\
\ldots \\
b_{m-1} \\
b_{m}
\end{array}\right], y=\left[\begin{array}{c}
\Lambda_{1} / s_{1} \\
\Lambda_{2} / s_{2} \\
\ldots \\
\Lambda_{k-1} / s_{k-1} \\
\Lambda_{k} / s_{k}
\end{array}\right] .
\end{gathered}
$$

We represent the matrix of system (4) in the form

$$
M=F K,
$$

where $K$ is the matrix, $F$ is the matrix of the discrete Fourier transform $[9,10]$

$$
\begin{aligned}
& F_{i, j}=S(i, j), \\
& S(i, j)=s_{1+q((i-1)(j-1))}, i=1,2, \ldots, k-1 ; j=1,2, \ldots, k-1, \\
& q(x)=x \bmod k .
\end{aligned}
$$

Its inverse matrix is defined by the formula

$$
F_{i, j}^{-1}=\frac{1}{k} \bar{S}(i, j) \text {. }
$$


Multiplying $F^{-1}$ by (4), we bring the system to the form

$$
K x=z,
$$

where $K=F^{-1} M, z=F^{-1} y$.

For $m>0$, the matrix $K$ has a cellular structure of the form

$$
K=\left[\begin{array}{cc}
E & C \\
0 & D
\end{array}\right] .
$$

where $E$ and 0 are the identity and zero matrices of size $n \times n$ and $m \times n, C$ and $D$ are Toeplitz matrices of size $n \times m$ and $m \times m$, respectively.

Indeed, the blocks of matrices $F^{-1}$ and $M$ of cells $1 \times 1 \ldots n \times n$ are mutually inverse matrices of the discrete Fourier transform, therefore, their product will give the identity matrix $E$. The elements of the block of cells $m+1, k \ldots 1 \times n$ are obtained by multiplying the rows of the matrix $F^{-1}$ and the columns of the matrix $M$, which are also elements of the direct and inverse matrices of Fourier transform. The sums of their products, which give the offdiagonal elements of the identity matrix, will be zeros by analogy with how it is for the zero elements of the block $E$ located above them.

The nature of the matrices $C$ and $D$ is explained by the fact that the elements of the columns of the matrix $M$ for $j>n$ are formed by the sums of the products of the shifted elements of the matrices $F$ and the elements of the vector $\Gamma$, which are different from unity. In such cases, their scalar products give Toeplitz matrices [8].

Similarly, one can show that the matrix

$$
L=\left[\begin{array}{l}
C \\
D
\end{array}\right]_{n \times m}
$$

is a rectangular circulant of the form

$$
L=\left[\begin{array}{ccccc}
l_{1} & l_{k} & \ldots & l_{n+3} & l_{n+2} \\
l_{2} & l_{1} & \ldots & l_{n+4} & l_{n+3} \\
\ldots & \ldots & \ldots & \ldots & \ldots \\
l_{k-1} & l_{k-2} & \ldots & l_{n+1} & l_{n} \\
l_{k} & l_{k-1} & \ldots & l_{n+2} & l_{n+1}
\end{array}\right] .
$$

and $C$ and $D$ are persymmetric Toeplitz matrices

$$
\begin{gathered}
C_{n \times m}=\left[\begin{array}{ccccc}
l_{1} & l_{k} & \ldots & l_{n+3} & l_{n+2} \\
l_{2} & l_{1} & \ldots & l_{n+4} & l_{n+3} \\
\ldots & \ldots & \ldots & \ldots & \ldots \\
l_{n-1} & l_{n-2} & \ldots & l_{2} & l_{1} \\
l_{n} & l_{n-1} & \ldots & l_{3} & l_{2}
\end{array}\right], \\
D_{m \times m}=\left[\begin{array}{ccccc}
l_{n+1} & l_{n} & \ldots & l_{m+1} & l_{m} \\
l_{n+2} & l_{n+1} & \ldots & l_{m+2} & l_{m+1} \\
\ldots & \ldots & \ldots & \ldots & \ldots \\
l_{k-2} & l_{k-3} & \ldots & l_{n+1} & l_{n} \\
l_{k-1} & l_{k-2} & \ldots & l_{n+2} & l_{n+1}
\end{array}\right] .
\end{gathered}
$$

(C) Kodnyanko V. A., 2020

DOI $10.15588 / 1607-3274-2020-4-5$
Vector $l$ coincides with $n+1$ columns of matrix $K$

$$
\begin{aligned}
& l_{i}=\sum_{j=1}^{k} F_{i, j}^{-1} M_{j, n+1}=\frac{1}{k} \sum_{j=1}^{k} \Gamma_{j} \bar{S}(i, j), \\
& i=1,2, \ldots, k .
\end{aligned}
$$

Similarly, one can show that the first $k-1$ elements of the vector $z$

$$
z_{j}=-b_{0} l_{j+1}, j=1,2, \ldots, k-1
$$

and the last element

$$
z_{k}=\frac{1}{k} \sum_{j=1}^{k} \Gamma_{j}
$$

Thus, vectors $l$ and $z$, matrices $C$ and $D$ can be obtained using vectors $s$ and $\Psi$ without using matrices $K$, $F^{-1}$ and $M$.

In the case $m=0$, system (4) takes the form

$$
F a=y,
$$

therefore, $a=\mathrm{z}$ and the problem of rational interpolation of the TF is solved.

It follows from (5)-(8) that for $m>0$ the vector $b$ of the TF coefficients (1) satisfies the system of equations

$$
D b=d,
$$

where $d$ is a vector composed of the last $m$ elements of the vector $z$

$$
d_{i}=z_{n+i}, \quad i=1,2, \ldots, m .
$$

In comparison with the original equation (3), which has the order $k=n+m$, equation (10) has a much smaller order $m<k / 2$. Consequently, his solution can be obtained much faster.

Equation (10) is a standard problem with an asymmetric Toeplitz matrix of a special type [13, 14, 22], which can be solved both by general methods, for example, the Gauss-Jordan method [11], the complexity of which is proportional to $\mathrm{m}^{3}$, and by special fast methods taking into account the features of Eq. (10) and having a complexity proportional to $\mathrm{m} 2$. The latter include the methods of Trench, Berlekamp-Massey, Euclid $[10-15,22]$.

Elements of the matrix $C$ can be expressed in terms of the vector $l$

$$
C_{i, j}=l_{q(k+i-j)}, \quad i=1,2, \ldots, n ; \quad j=1,2, \ldots, m .
$$

Taking this into account, one can do without matrix $C$ and, using the solution to system (10), quickly find the $\mathrm{HP}$ coefficients using the complexity formula $\mathrm{nm}$

$$
a_{i}=l_{i}-\sum_{j=1}^{m} l_{q(k+i-j)} b_{j}, \quad i=1,2, \ldots, n .
$$

Taking this into account, the total order of complexity of this method for finding the coefficients (1) is $m(n+m)$. 
In those cases when $s=s_{j}$ is the zero of the TF or it is necessary to find only the HP coefficients, another approach can be applied.

Let us rewrite equation (3) in the form

$$
\begin{gathered}
b_{1}+b_{2} s+\ldots+b_{m} s^{m-1}-\Phi(s)\left(a_{1}+a_{2} s+\ldots+a_{n} s^{n-1}\right)= \\
=\frac{\Phi(s)-b_{0}}{s} .
\end{gathered}
$$

Following the above method, the procedure for finding the HP coefficients can be reduced to solving a system of equations of a lower order $n<k$

$$
D a=d,
$$

where

$$
\begin{gathered}
D_{n \times n}=-\left[\begin{array}{ccccc}
l_{m-1} & l_{m-2} & \ldots & l_{2 m+1} & l_{2 m} \\
l_{m} & l_{m-1} & \ldots & l_{2 m+2} & l_{2 m+1} \\
\ldots & \ldots & \ldots & \ldots & \ldots \\
l_{k-3} & l_{k-4} & \ldots & l_{m-1} & l_{m-2} \\
l_{k-2} & l_{k-3} & \ldots & l_{m} & l_{m-1}
\end{array}\right], \\
l_{i-1}=\frac{1}{k} \sum_{j=1}^{k} \Phi\left(s_{j}\right) S(i, j), \quad i=1,2, \ldots, k . \\
l_{k}=l_{k-1}-b_{0}, \\
d_{i}=l_{m+i-1}, \quad i=1,2, \ldots, n-1, \\
d_{n}=l_{k} .
\end{gathered}
$$

In comparison with (10), system (12), as a rule, has a slightly higher order $n>m$, but its solution allows one to immediately find the HP coefficients, bypassing the procedure for finding the polynomial of the TF numerator. System (12) can also be solved by the mentioned fast methods with order of complexity $n^{2}$.

\section{EXPERIMENTS}

To assess the quality of the dynamics of linear automatic control systems, root criteria are often used [16, 17]:

- the degree of stability $\eta=\operatorname{Max} \operatorname{Re}\{s i\}$, where si are the zeros of the characteristic polynomial of the dynamical system, which is the denominator polynomial of the TF (1),

- damping of oscillations for a period $\xi=100[1-\operatorname{Exp}(-\mid 2 \pi \beta / \eta]] \%$, where $\beta$ is the imaginary part of the root of the characteristic equation with the largest real part.

The degree of stability $\eta$ characterizes the speed of the system, that is, the speed of damping of its free oscillations.

The criterion $\xi$ of damping of oscillations over a period can be applied to the assessment of the stability margin of the system. The smaller $\xi$, the more oscillation the transient response will have, and the system will have a smaller stability margin. It is believed that a dynamic system is well damped if $\xi \geq 90 \%$ [17].
At the beginning, using the algorithm for calculating the values of the transfer function, it is necessary to determine the power difference by the TF polynomial $p=$ $n-m$ based on (2).

Further calculations are performed using the following iterative process.

Step 1. Put $i=1$ and $m=1, m=1, \eta_{0}=i n f, \xi_{0}=$ inf, where inf is a large number (for example, inf $=10^{10}$ ), specify the accuracy of determining the degree of stability $\varepsilon_{\eta}$ and damping of oscillations over the period $\varepsilon_{\xi}$.

Step 2. Calculate $n=p+m$ and, performing rational interpolation by formula (11), find the vector $a$ of the HP coefficients.

Step 3. Determine the roots of the characteristic equation, find the root with the largest real part among them and calculate the criteria $\eta_{i}$ and $\xi_{i}$.

Step 4. Check the conditions for convergence of the iterative process to the solution

$$
\left|\eta_{i}-\eta_{i-1}\right|<\varepsilon_{\eta}, \quad\left|\xi_{i}-\xi_{i-1}\right|<\varepsilon_{\xi} .
$$

Step 5. If conditions (12) are met, then the quality criteria of the system dynamics are determined with the required accuracy, otherwise the process should be continued. To do this, it is necessary to increase the values of the iteration counter $i$ and degree $m$ by one and go to the step 2 .

\section{RESULTS}

As a test problem for determining the quality criteria of the dynamics of a system with distributed parameters, a model of unsteady motion of an axial support with gas lubrication was considered [18].

After linearization and application of the integral Laplace transform to a linear model, a transfer function necessary for calculations was obtained, the calculation of the value of which includes the numerical solution of several boundary value problems for the Reynolds differential equation [19] of the form

$$
\left\{\begin{array}{l}
\frac{d}{d R}\left[R \frac{d(P u)}{d R}\right]=\frac{\sigma s}{H^{3}} R(H u+\alpha P), \\
u\left(r_{b}, s\right)=u_{b}, \quad u\left(r_{e}, s\right)=u_{e},
\end{array}\right.
$$

where $u(R, s)$ is the required function,

$$
P(R)=\sqrt{\left(P_{e}^{2}-P_{b}^{2}\right) \frac{\ln \left(R / R_{b}\right)}{\ln \left(R_{e} / R_{b}\right)}+P_{b}^{2}}
$$

is function of static gas pressure in the lubricating layer; $\alpha, \alpha, H, r_{b}, r_{e}, P_{b}, P_{e}$ are constants, $s$ is the Laplace transform variable.

Problem (13) does not have an exact analytical solution; therefore, a numerical finite-difference sweep method was applied to it, where the variable s played the role of a complex parameter [20].

The numerical solution of problems (13) gives a result of high accuracy, but this approach does not allow 
explicitly obtaining the transfer function and, in particular, the HP.

The solution was found in sequential iterative rational interpolation, the results of which were used to calculate the quality criteria for the support dynamics with a given accuracy.

The calculation algorithm is as follows. For the accepted variant, the combination of the values of the input parameters was first calculated $b_{0}=\Phi(0)=0.15934$, then the difference in the degrees of the TF polynomials $p=n-m$ was determined. The result is shown in Table 1.

From Table 1 it follows that the smallest $p>0$, at which $s^{p} \Phi(s)$ converges to a nonzero limit, $p=2$.

Taking $\varepsilon_{\eta}=10^{-3}, \varepsilon_{\xi}=0.1$ and the order of the polynomial of the numerator of the TF $m=0$, we found the initial order of the characteristic polynomial $n=p+m=2$

Table $1-$ Determination of the difference $p=n-m$

\begin{tabular}{|r|r|c|c|}
\hline$N$ & \multicolumn{1}{|c|}{$s$} & $s \Phi(s)$ & $s^{2} \Phi(s)$ \\
\hline 1 & 1 & 0.15934 & 0.15904 \\
\hline 2 & 10 & 0.09345 & 0.93415 \\
\hline 3 & 100 & 0.00996 & 0.99926 \\
\hline 4 & 1000 & 0.00099 & 0.99999 \\
\hline
\end{tabular}

Then, an iterative process was performed, at each step of which $m$ was increased by one, $n=p+m$ was found, the problem of rational interpolation of the TF was solved, and the quality criteria of the system dynamics were calculated.

\section{DISCUSSION}

The conditions (12) for the convergence of the iterative process were fulfilled at the fourth iteration. This means that for a sufficiently accurate representation of the transfer function of the system from a practical point of view, the order of the polynomial of its numerator is $n=5$, and the order of the denominator is $m=3$. In this case, system (10) took the form

$$
\left(\begin{array}{ccc}
-0.026 & 0.057 & -0.161 \\
0.056 & -0.026 & 0.057 \\
-0.405 & 0.056 & -0.026
\end{array}\right)\left(\begin{array}{l}
b_{1} \\
b_{2} \\
b_{3}
\end{array}\right)=\left(\begin{array}{c}
-0.008 \\
0.056 \\
-0.457
\end{array}\right) .
$$

Her decision

$$
\left(\begin{array}{l}
b_{1} \\
b_{2} \\
b_{3}
\end{array}\right)=\left(\begin{array}{l}
1.202 \\
0.560 \\
0.055
\end{array}\right)
$$

With rational interpolation of the $\mathrm{TF}$, the most time consuming part of the procedure for finding eight unknown coefficients $a_{1}, a_{2}, a_{3}, a_{4}, a_{5}, b_{1}, b_{2}, b_{3}$ of the TF was reduced to solving system (14) of the third order.
Thus, with the help of rational interpolation, the considered transfer function can be represented with an accuracy sufficient for practice in the form

$$
\Phi(s)=\frac{b_{0}+b_{1} s+b_{2} s^{2}+b_{3} s^{3}}{1+a_{1} s+a_{2} s^{2}+a_{3} s^{3}+b_{4} s^{4}+b_{5} s^{5}} .
$$

The criterion for the speed of the system $\eta=0.233>0$, the criterion for the damping of oscillations over the period $\xi=100 \%$. This means that the system is stable and characterized by the absence of oscillation, which indicates the high quality of its dynamics.

\section{CONCLUSIONS}

The paper proposes a fast method of rational interpolation of the transfer function of linear systems with distributed parameters, the values of which can be found by numerical methods or in another way, for example, by calculating the transcendental functions of the Laplace integral transform variable. The method allows to define explicitly the characteristic equation of such a degree, which is sufficient to meet the accuracy requirements when calculating the root quality criteria for the dynamics of automatic control systems.

According to the proposed method, rational interpolation is reduced to solving a system of linear equations, the order of which is much lower (more than twice) the order of similar systems used for rational interpolation of functions by known methods. The properties of this system are such that, if necessary, its solution can be obtained by special fast methods of the quadratic order of complexity.

A demonstration algorithm for calculating the root quality criteria of an automatic control system is considered on the example of assessing the quality of the dynamics of a support with gas lubrication. The algorithm made it possible to calculate the quality criteria with the required accuracy in four iterations, at each of which a rational interpolation of the transfer function obtained by solving several problems for differential equations by the high-precision finite-difference sweep method was performed.

\section{ACKNOWLEDGEMENTS}

The work was carried out within the framework of the scientific research budget themes «Methods of modeling and optimizing of quality control information systems on the basis of intellectual technologies») at the Department of Standardization, Metrology and Quality Management of the Polytechnic Institute of the Siberian Federal University.

\section{REFERENCES}

1. Fraleigh J. B., Beauregard R. A. Linear Algebra. AddisonWesley, 1995, $608 \mathrm{p}$.

2. Riley K. F., Hobson M. P., Bence S. J. Mathematical methods for physics and engineering. Cambridge University Press, 2010, 455 p. 
3. Middlebrook R. D. Input filter considerations in design and application of switching regulators, IEEE Industry Applications Society Annual Meeting, 1976, pp. 366-382.

4. Carrol J. An input impedance stability criterion allowing more flexibility for multiple loads which are independently designed, Naval Air Warfare Center, Aircraft Division, Indianapolis, B/812, 1992.

5. Wildrick C. M., Lee F. C., Cho B. H., Choi B. A method of defining the load impedance specification for a stable distributed power system, IEEE Transactions on Power Electronics, 1995, pp. 280-285.

6. Kodnyanko V. A. Stability of energy-saving adaptive radial hydrostatic bearing with limitation of the output flow of lubricant, Journal of the Siberian Federal University. Technics and technology, Krasnoyarsk, 2011, Vol. 6, No. 4, pp. 907-914.

7. Bradie B.A. Friendly Introduction to Numerical Analysis, Upper Saddle River, New Jersey: Pearson Prentice Hall, 2006.

8. Smith S.W. Chapter 8: The Discrete Fourier Transform, The Scientist and Engineer's Guide to Digital Signal Processing, San Diego, Calif.: California Technical Publishing, 1999.

9. Golub G. H., Van Loan C. F. Matrix computations, John Hopkins Studies in the Mathematical Sciences, Johns Hopkins University Press, Baltimore, MD, 1996.

10. Heinig G., Rost K., Efficient inversion formulas for Toeplitz-plus-Hankel matrices using trigonometric transformations, Structured Matrices in Mathematics, Computer Science, and Engineering, II, Contemp. Math., Amer. Math. Soc., Providence, RI, 2001, vol. 281, pp. 247 264.

11. Beale E. M. L. Cycling in the dual simplex algorithm, Naval Research Logistics Quarterly, 1955, 2 (4), pp. 269-276. DOI: $10.1002 /$ nav.3800020406.
12. Voevodin V. V., Tyrtyshnikov E. E. Toeplitz matrices and their applications, Computing Methods in Applied Sciences and Engineering, North-Holland, Amsterdam, 1984, pp. 7585 .

13. Trench W. F. An algorithm for the inversion of finite Hankel matrices, SIAMJ. Appl. Math, 13, 1965, pp. 1102-1107.

14. Zohar S. Toeplitz matrix inversion: The algorithm of W. F. Trench, J. Assoc. Comput, Mach.16, 1967, pp. 592-601.

15. Petrov O. A. A fast algorithm for solving systems of equations with a Toeplitz matrix, Infocommunication technologies, 2006, Vol. 4, No. 1, pp. 57-59.

16. Rahman Q. I., Schmeisser G. Analytic theory of polynomials, London Mathematical Society Monographs, New Series, 26, Oxford: Oxford University Press, 2002.

17. Besekersky V. A., Popov E. P. Theory of automatic control systems, Saint Petersburg, Profession, 2003,752 p.

18. Kodnyanko V. A. Numerical calculation of the static characteristics of a single-row slotted gas-static suspension, Problems of mechanical engineering and reliability of machines, 2002, No. 2, pp. 17-19.

19. Constantinescu V. N. Gas Lubrication, New York: American Society of Mechanical Engineers, 1969.

20. Muir T. A treatise on the theory of determinants, Dover Publications, 1960, pp. 516-525.

21. Press W. H., Teukolsky S. A., Vetterling W. T., Flannery B. P. Rational Function Interpolation and Extrapolation, Numerical Recipes in C. Cambridge: Cambridge University Press, 1994

22. Blahut R.E. Fast Algorithms for Signal Processing, Cambridge University Press, 2010, 469 p. DOI: $10.1017 /$ CBO9780511760921.

Received 21.09.2020 Accepted 27.10.2020

\section{УДК 519.67}

\section{ШВИДКА РАЦІОНАЛЬНА ІНТЕРПОЛЯЦІЯ ПЕРЕДАТОЧНИХ ФУНКЦІЙ ЛІНІЙНИХ ДИНАМІЧНИХ СИСТЕМ $З$ РОЗПОДІЛЕНИМИ ПАРАМЕТРАМИ}

Коднянко В. А. - д-р техн. наук, професор кафедри стандартизації, метрології та управління якістю. Політехнічний інститут Сибірського федерального університету, Красноярськ, Росія.

\section{АНОТАЦІЯ}

Актуальність. Викладається швидкий метод раціональної інтерполяції передавальної функції лінійних динамічних систем з розподіленими параметрами, значення якої можуть бути знайдені чисельними методами або розрахунком трансцендентних функцій змінної інтегрального перетворення Лапласа. Метод дозволяє визначити в явному вигляді передавальну функцію i, зокрема, характеристичне рівняння такої міри, яка достатня для задоволення вимог точності при розрахунку кореневих критеріїв якості динаміки систем автоматичного управління.

Мета. Відповідно до запропонованого методу раціональна інтерполяція зводиться до вирішення системи лінійних рівнянь, порядок якої значно нижче (більш ніж удвічі) порядку аналогічних систем, що застосовуються для раціональної інтерполяції функцій відомими методами. Властивості цієї системи є такими, що іiі рішення може бути отримано спеціальними швидкими методами квадратичного порядку складності.

Метод. Ітераційний алгоритм розрахунку коефіцієнтів передавальної функції лінійної динамічної системи 3 розподіленими параметрами проведено з використанням методів теорії функцій комплексної змінної з використанням дискретного перетворення Лапласа. Запропонований підхід дозволив значно прискорити розрахунки за допомогою декомпозиції системи лінійних рівнянь щодо коефіцієнтів передавальної функції до системи приблизно вдвічі меншого порядку, яка допускає швидке рішення методами Тренча, Берлекампа-Мессі або Евкліда.

Результати. Розглянуто приклад практичного використання ітераційного алгоритму раціональної інтерполяції і обчислення із заданою точністю кореневих критеріїв якості динаміки опори з газової мастилом.

Висновки. Метод дозволяє явно визначити характеристичне рівняння такої міри, яка достатня для виконання вимог точності при обчисленні кореневих критеріїв якості динаміки систем автоматичного управління. Раціональна інтерполяція зводиться до вирішення системи лінійних рівнянь, порядок якої набагато нижче (більш ніж в два рази) порядку аналогічних систем, використовуваних для раціональної інтерполяції функцій відомими методами. Властивості системи такі, що іiї рішення може бути отримано спеціальними швидкими методами квадратичного порядку складності.

КЛЮЧОВІ СЛОВА: раціональна інтерполяція, лінійна динамічна система, передавальна функція, система 3 розподіленими параметрами, дискретне перетворення Фур'€. 


\section{БЫСТРАЯ РАЦИОНАЛЬНАЯ ИНТЕРПОЛЯЦИЯ ПЕРЕДАТОЧНЫХ ФУНКЦИЙ ЛИНЕЙНЫХ ДИНАМИЧЕСКИХ} СИСТЕМ С РАСПРЕДЕЛЕННЫМИ ПАРАМЕТРАМИ

Коднянко В. А. - д-р техн. наук, профессор кафедры стандартизации, метрологии и управления качеством. Политехнический институт Сибирского федерального университета, Красноярск, Россия.

\section{АННОТАЦИЯ}

Актуальность. Излагается быстрый метод рациональной интерполяции передаточной функции линейных динамических систем с распределенными параметрами, значения которой могут быть найдены численными методами либо расчетом трансцендентных функций переменной интегрального преобразования Лапласа. Метод позволяет определить в явном виде передаточную функцию и, в частности, характеристическое уравнение такой степени, которое достаточно для удовлетворения требований точности при расчете корневых критериев качества динамики систем автоматического управления.

Цель. Согласно предложенному методу рациональная интерполяция сводится к решению системы линейных уравнений, порядок которой значительно ниже (более чем вдвое) порядка аналогичных систем, применяемых для рациональной интерполяции функций известными методами. Свойства данной системы таковы, что ее решение может быть получено специальными быстрыми методами квадратичного порядка сложности.

Метод. Итерационный алгоритм расчета коэффициентов передаточной функции линейной динамической системы с распределенными параметрами проведен с использованием методов теории функций комплексной переменной с использованием дискретного преобразования Лапласа. Предложенный подход позволил значительно ускорить расчеты посредством декомпозиции системы линейных уравнений относительно коэффициентов передаточной функции к системе примерно вдвое меньшего порядка, которая допускает быстрое решение методами Тренча, Берлекампа-Месси или Евклида.

Результаты. Рассмотрен пример практического использования итерационного алгоритма рациональной интерполяции и вычисления с заданной точностью корневых критериев качества динамики опоры с газовой смазкой.

Выводы. Метод позволяет явно определить характеристическое уравнение такой степени, которая достаточна для выполнения требований точности при вычислении корневых критериев качества динамики систем автоматического управления. Рациональная интерполяция сводится к решению системы линейных уравнений, порядок которой намного ниже (более чем в два раза) порядка аналогичных систем, используемых для рациональной интерполяции функций известными методами. Свойства системы таковы, что ее решение может быть получено специальными быстрыми методами квадратичного порядка сложности.

КЛЮЧЕВЫЕ СЛОВА: рациональная интерполяция, линейная динамическая система, передаточная функция, система с распределенными параметрами, дискретное преобразование Фурье.

\section{ЛИТЕРАТУРА / ЛІТЕРАТУРА}

1. Fraleigh J. B. Linear Algebra / J. B. Fraleigh, R. A. Beauregard // Addison-Wesley, 1995. $-608 \mathrm{p}$.

2. Riley K. F. Mathematical methods for physics and engineering/ K. F. Riley, M. P. Hobson, S. J. Bence // Cambridge University Press, 2010. $-455 \mathrm{p}$.

3. Middlebrook R. D. Input filter considerations in design and application of switching regulators / R. D. Middlebrook // IEEE Industry Applications Society Annual Meeting. - 1976. - P. 366382.

4. Carrol J. An input impedance stability criterion allowing more flexibility for multiple loads which are independently designed / J. Carrol // Naval Air Warfare Center. Aircraft Division. Indianapolis. B/812. - 1992.

5. A method of defining the load impedance specification for a stable distributed power system / [C. M. Wildrick, F. C. Lee, B. H. Cho, B. Choi] // IEEE Transactions on Power Electronics. - 1995. P. 280-285.

6. Коднянко В. А. Устойчивость энергосберегающей адаптивной радиальной гидростатической опоры с ограничением выходного потока смазки / В. А. Коднянко // Журнал Сибирского федерального университета. Техника и технологии, Красноярск. - 2011. - Т. 6, № 4. - С. 907-914.

7. Bradie B. A. Friendly Introduction to Numerical Analysis / B. A. Bradie // Upper Saddle River. New Jersey : Pearson Prentice Hall. - 2006

8. Smith S. W. Chapter 8: The Discrete Fourier Transform / S. W. Smith // The Scientist and Engineer's Guide to Digital Signal Processing. San Diego. Calif.: California Technical Publishing. 1999.

9. Golub G. H. Matrix computations / G. H. Golub, C. F. Van Loan // Johns Hopkins Studies in the Mathematical Sciences, Johns Hopkins University Press. Baltimore. - 1996.

10. Heinig G. Efficient inversion formulas for Toeplitz-plus-Hankel matrices using trigonometric transformations / G. Heinig, K. Rost // Structured Matrices in Mathematics. Computer Science. and Engineering. II. Contemp. Math. Vol. 281. Amer. Math. Soc. Providence. RI. - 2001. - P. 247-264.
11. Beale E. M. L. Cycling in the dual simplex algorithm/ E. M. L. Beale // Naval Research Logistics Quarterly2 (4). - 1955. P. 269-276. DOI: 10.1002/nav.3800020406.

12. Voevodin V. V. Toeplitz matrices and their applications / V. V. Voevodin, E. E. Tyrtyshnikov // Computing Methods in Applied Sciences and Engineering. North-Holland. Amsterdam. 1984. - P. 75-85.

13. Trench W. F. An algorithm for the inversion of finite Hankel matrices / W. F. Trench // SIAMJ. Appl. Math. - 13. - 1965. - P. 1102-1107.

14. Zohar S. Toeplitz matrix inversion: The algorithm of W. F. Trench / S. Zohar // J. Assoc. Comput, Mach, 16. - 1967. - P. 592-601.

15. Петров О. А. Быстрый алгоритм решения систем уравнения с теплицевой матрицей / О. А. Петров // Инфокоммуникационные технологии. - 2006. - Том 4, № 1. C. 57-59.

16. Rahman Q. I. Analytic theory of polynomials / Q. I. Rahman, G. Schmeisser // London Mathematical Society Monographs. -New Series. 26. Oxford : Oxford University Press. - 2002.

17. Бесекерский В. А. Теория систем автоматического регулирования / В. А. Бесекерский, Е. П. Попов // Спб.: Профессия, 2003. - 752 с.

18. Коднянко В. А. Численный расчет статических характеристик однорядного щелевого газостатического подвеса / В. А. Коднянко // Проблемы машиностроения и надежности машин. - 2002. - № 2. - С. 17-19.

19. Constantinescu V. N. Gas Lubrication / V. N. Constantinescu // New York: American Society of Mechanical Engineers. - 1969.

20. Muir T. A treatise on the theory of determinants / T. Muir // Dover Publications. -1960 . - P. 516-525.

21. Rational Function Interpolation and Extrapolation / [W. H. Press, S. A. Teukolsky, W. T. Vetterling, B. P. Flannery] // Numerical Recipes in C. Cambridge: Cambridge University Press. - 1994.

22. Blahut R. E. Fast Algorithms for Signal Processing / R. E. Blahut. Cambridge University Press, 2010. - 469 p. DOI: $10.1017 / \mathrm{CBO} 9780511760921$. 